\title{
APLIKASI PAKAN BUATAN PADA PEMELIHARAAN BENIH ABALON (Haliotis squamata)
}

\author{
Muhammad Marzuqi, Ibnu Rusdi, dan Bambang Susanto \\ Balai Besar Penelitian dan Pengembangan Budidaya Laut \\ JI. Br. Gondol Kec. Gerokgak Kab. Buleleng, Kotak Pos 140, Singaraja-Bali 81101 \\ E-mail: rimgdl@indosat.net.id
}

(Naskah diterima: 28 Desember 2011; Disetujui publikasi: 4 Juli 2012)

\begin{abstract}
ABSTRAK
Penelitian ini bertujuan untuk mengetahui penggunaan pakan buatan yang sesuai untuk pertumbuhan benih abalon (Haliotis squamata). Penelitian dilakukan di Laboratorium Nutrisi, Balai Besar Penelitian dan Pengembangan Budidaya Laut, GondolBali. Wadah yang digunakan berupa 3 buah bak polikarbonate/fiber bervolume $400 \mathrm{~L}$, dengan menggunakan sistem air mengalir. Masing-masing bak diletakkan 4 keranjang yang berisi benih abalon dengan ukuran panjang cangkang 14,36 1,59 $\mathrm{mm}$ dan bobot awal 0,51 $\pm 0,15 \mathrm{~g}$ dengan kepadatan 20 ekor. Perlakuan berupa empat jenis pakan buatan dengan proporsi makroalga yaitu (A) Ulva sp. : Gracilaria sp. = 4:0; (B) Ulva sp. : Gracilaria sp. $=3: 1 ;$ (C) Ulva sp. : Gracilaria sp. $=2: 2 ;$ (D) Ulva sp. : Gracilaria $=1: 3$. Penelitian menggunakan rancangan acak lengkap dan setiap perlakuan diulang 3 kali. Pengukuran panjang cangkang dilakukan setiap 7 hari. Penimbangan bobot dilakukan pada awal dan akhir penelitian. Frekuensi pemberian pakan sebanyak 2 kali setiap hari. Hasil penelitian menunjukkan bahwa pakan buatan dengan proporsi makroalga berpengaruh nyata terhadap pertumbuhan panjang cangkang, bobot akhir, dan pertambahan bobot benih abalon (Haliotis squamata) $(\mathrm{P}<0,05)$. Pertumbuhan panjang cangkang, bobot akhir, dan pertambahan bobot yang terbaik adalah perlakuan pemberian pakan dengan proporsi makroalga Ulva sp. dan Gracilaria sp. = 4:0 yaitu sebesar 21,00 mm; 1,48 g; dan 189,54\%.
\end{abstract}

KATA KUNCI: pakan buatan, pertumbuhan, abalon, Haliotis squamata

ABSTRACT: Application of artificial diet on rearing of abalone (Haliotis squamata) juveniles. By: Muhammad Marzuqi, Ibnu Rusdi, and Bambang Susanto

This experiment was purpose to obtain the information of suitable artificial diet to promote the growth of abalone juveniles. The experiment was conducted in nutrition laboratory of Gondol Research Institute for Mariculture, Bali. Abalone were stocked in 3 polycarbonate/fibre tanks of 400 liters and equipped with flow-throw system. Densities are 20 pcs in each compartment with average shell length was $14.36 \pm 1.59$ $\mathrm{mm}$ and initial body weight was $0.51 \pm 0.15 \mathrm{~g}$. Each polycarbonate put four compartment. The experimental using four of artificial diet with propotion of macroalgae i.e. (A) Ulva sp. : Gracilaria sp. = 4:0, (B) Ulva sp. : Gracilaria $s p .=3: 1$, (C) Ulva sp. : Gracilaria sp. $=2: 2$, (D) Ulva sp. : Gracilaria $s p .=1: 3$. The experiment designed using completely randomized design with four treatments, each three replications. Feeding frequency was two times daily. The shell length of abalone measured every seven days through shell length by individually each tank. Body weight was measured on initial and final of experiment. The result showed that the artificial diet with ingredients proportion of macroalgae was significantly differences 
$(P<0.05)$ on the growth of length shell, final body weight and body weight gain of abalone (Haliotis squamata) juveniles. The highest growth of shell length, final body weight and weight gain were obtained on artificial diet with ingredients proportion of macroalgae i.e. Ulva sp. : Gracilaria sp. $=4: 0$ each $21.00 \mathrm{~mm}, 1.48 \mathrm{~g}$, and $189.54 \%$, respectively.

\section{KEYWORDS: artificial diet, growth, abalone, Haliotis squamata}

\section{PENDAHULUAN}

Abalon merupakan satu di antara komoditas laut yang mempunyai nilai ekonomis tinggi, sehingga permintaan dari tahun ke tahun terus mengalami peningkatan. Pasar utama abalon yaitu negara-negara Asia di antaranya Cina, Hong Kong, Korea, Jepang, dan Singapura, serta Amerika Serikat dan Negara Uni Eropa. Sampai saat ini produksi abalon masih didominasi dari hasil penangkapan di alam dan hanya sebagian kecil yang dihasilkan dari kegiatan budidaya (Gordon \& Cook, 2004). Di Indonesia produksi abalon masih mengandalkan tangkapan dari alam, Hal ini akan mengakibatkan populasi abalon di alam dari tahun ke tahun mengalami penurunan.

Untuk mengantisipasi kebutuhan benih abalon maka diperlukan usaha pembenihan abalon yang diharapkan dapat menyuplai benih secara berkesinambungan baik dari segi jumlah, ukuran, maupun waktu. Di Indonesia ditemukan beberapa spesies abalon, namun yang dewasa ini memiliki pasar dan sudah berhasil perbenihannya yaitu spesies Haliotis asinina dan Haliotis squamata (Priyambodo et al., 2005). Keberhasilan budidaya perbenihan di berbagai negara seperti, Cina, Jepang, Filipina, Australia termasuk di Indonesia, memacu pengembangan budidaya pembesaran yang bisa dilakukan outdoor di laut maupun indoors (Chen et al. dalam Fleming \& Hone, 1996). Di Balai Besar Penelitian dan Pengembangan Budidaya Laut, Gondol-Bali telah mulai melakukan serangkaian riset tentang perbenihan abalon, khususnya untuk spesies $H$. squamata (Susanto et al., 2007; Rusdi et al., 2009; Rahmawati et al., 2008; 2009). Hasil ujicoba pemeliharaan benih abalon pada skala laboratorium sudah mengalami peningkatan dan menghasilkan sintasan hingga 14\% (Komunikasi Pribadi).

Dalam pemeliharaan pada stadia larva umumnya abalon memakan diatom bentik seperti Nitzschia sp., Navicula sp., Amphora sp., Cocconeis sp., Rizosolenia sp. sedangkan ukuran yuwana sampai dewasa memakan makroalga (seaweed) yang terbagi atas tiga jenis, yaitu alga coklat (Laminaria), alga hijau (Ulva sp.), dan alga merah (Gracilaria sp.). Alga merah adalah jenis pakan alami yang dilaporkan baik bagi induk abalon $H$. asinina (Singhagraiwan et al., 1992), dan abalon $H$. squamata (Susanto et al., 2007). Namun juga diketahui bahwa abalon sangat menyukai jenis alga hijau yang bertekstur lunak seperti Ulva sp., sedangkan alga coklat di antaranya Sargassum sp. dilaporkan kaya akan kandungan asam lemak tak jenuh (Chen $\&$ Chen, 2000; Rusdi et al., 2009). Ketersediaan makanan bagi abalon yang baru memasuki masa post larva adalah penting, karena hal ini berkaitan dengan sintasannya (Takami et al., 2000 dalam Octaviany, 2007). Laju pertumbuhan pada fase hidup awal abalon bergantung pada ketersediaan makanan dan kemampuan masing-masing individu dalam memanfaatkan makanan yang tersedia. Tingkat kematian yang tinggi terjadi apabila benih abalon tidak segera memperoleh pakan yang sesuai, baik jenis maupun jumlahnya.

Hambatan utama dalam pengembangan pembesaran abalon di antaranya adalah ketersediaan data kesesuaian pakan. Penggunaan pakan alami mempunyai kelemahan yaitu jumlah dan bergantung pada musim, sedangkan pakan buatan dapat disusun berdasarkan kebutuhan hewan yang dibudidayakan. Pakan benih abalon harus mengandung gizi yang dibutuhkan berupa protein, lemak, karbohidrat, vitamin, dan mineral. Mengacu pada keberhasilan dan permasalahan di atas maka pengembangan pakan untuk benih abalon perlu dilakukan. Hal ini untuk mengantisipasi perkembangan budidaya abalon dan untuk menekan kematian abalon dalam pembesaran.

Tujuan dari penelitian ini adalah mendapatkan informasi pakan buatan yang baik dan menunjang pertumbuhan abalon, Haliotis squamata yang optimal. 


\section{BAHAN DAN METODE}

Benih yang digunakan untuk pengamatan berasal dari telur hasil pemijahan buatan induk abalon, Haliotis squamata yang dipelihara dalam bak terkontrol di hatcheri Balai Besar Penelitian dan Pengembangan Budidaya Laut, Gondol-Bali. Penelitian dilakukan di Laboratorium Nutrisi selama 60 hari (2 bulan). Wadah yang digunakan 3 buah bak polikarbonat/ fiber dengan volume $400 \mathrm{~L}$. Masing-masing bak diletakkan 4 keranjang yang berisi benih abalon dengan ukuran panjang cangkang ratarata $14,36 \pm 1,59 \mathrm{~mm}$ dan bobot awal rata-rata $0,51 \pm 0,15 \mathrm{~g}$ dengan kepadatan 20 ekor/ keranjang. Perlakuan berupa empat jenis pakan buatan dengan proporsi makroalga yaitu (A)
Ulva sp.: Gracilaria sp. = 4:0; (B) Ulva sp. : Gracilaria sp. $=3: 1 ;$ (C) Ulva sp. : Gracilaria sp. $=2: 2 ;$ (D) Ulva sp. : Gracilaria sp. $=1: 3$. Kemudian campuran tersebut digunakan dalam formulasi pakan buatan (Tabel 1). Penelitian menggunakan rancangan acak lengkap dan setiap perlakuan diulang 3 kali. Pengamatan pertumbuhan benih dilakukan setiap 7 hari sekali yang meliputi pengukuran panjang cangkang. Penimbangan bobot dilakukan pada awal dan akhir penelitian. Frekuensi pemberian pakan sebanyak 2 kali setiap hari dan ukuran pakan disesuaikan dengan biota uji. Agar kondisi pemeliharaan abalon tetap bersih, maka setiap hari dilakukan penyiponan kotoran dalam bak pemeliharaan. Analisis proksimat dari pelet kering dengan menggunakan metode

Tabel 1. Komposisi pakan percobaan (g/100 g pakan)

Table 1. Composition of experimental diet ( $\mathrm{g} / 100 \mathrm{~g}$ dry diet)

\begin{tabular}{|c|c|c|c|c|}
\hline \multirow{2}{*}{$\begin{array}{l}\text { Bahan } \\
\text { Ingredients }\end{array}$} & \multicolumn{4}{|c|}{$\begin{array}{l}\text { Proporsi Ulva sp. dan Gracilaria sp. dalam pakan } \\
\text { Ulva sp. and Gracilaria sp. proportion in diet }\end{array}$} \\
\hline & (A) 4:0 & (B) $3: 1$ & (C) $2: 2$ & (D) $1: 3$ \\
\hline Tepung ikan (Fish meal) & 17.00 & 17.00 & 17.00 & 17.00 \\
\hline $\begin{array}{l}\text { Tepung Ulva sp. } \\
\text { Ulva sp. meal }\end{array}$ & 41.00 & 30.75 & 20.50 & 10.25 \\
\hline $\begin{array}{l}\text { Tepung Gracilaria sp. } \\
\text { Gracilaria sp. meal }\end{array}$ & 0.00 & 22.67 & 45.33 & 68.00 \\
\hline Vitamin $\operatorname{mix}{ }^{1)}$ & 1.30 & 1.30 & 1.30 & 1.30 \\
\hline Mineral $\operatorname{mix}^{2)}$ & 1.70 & 1.70 & 1.70 & 1.70 \\
\hline Minyak ikan (Fish oil) & 1.19 & 0.13 & 0.06 & 0.00 \\
\hline Asthaxanthin & 0.10 & 0.10 & 0.10 & 0.10 \\
\hline CMC (Binder) & 1.50 & 1.50 & 1.50 & 1.50 \\
\hline Selulosa (Celluloce) & 36.21 & 24.85 & 12.51 & 0.15 \\
\hline Total & 100.00 & 100.00 & 100.00 & 100.00 \\
\hline \multicolumn{5}{|l|}{$\begin{array}{l}\text { Analisis proksimat } \\
\text { Proximate analysis (\%) }\end{array}$} \\
\hline Protein & 18.70 & 19.54 & 18.33 & 19.02 \\
\hline Lemak (Lipid) & 2.51 & 1.79 & 1.65 & 1.40 \\
\hline Abu (Ash) & 11.42 & 21.37 & 33.13 & 42.36 \\
\hline Kadar air (Moisture) & 6.78 & 7.04 & 5.39 & 5.17 \\
\hline \multicolumn{5}{|c|}{$\begin{array}{l}\text { Vitamin } \operatorname{mix}(\mathrm{mg} / 100 \mathrm{~g} \text { pakan/diet): Thiamin- } \mathrm{HCl} 5.0 \text {; riboflavin } 5.0 \text {; Ca-pantothenate } 10.0 \text {; } \\
\text { niacin 2.0; pyridoxin-HCl 4.0; biotin 0.6; folic acid 1.5; cyanocobalamin } 0.01 \text {; inositol 200; } \\
\rho \text {-aminobenzoic acid 5.0; menadion 4.0; vit A palmitat } 15.0 \text {; chole-calciferol 1.9; } \\
\alpha \text {-tocopherol 20.0; cholin chloride } 900.0\end{array}$} \\
\hline \multicolumn{5}{|c|}{$\begin{array}{l}\text { Mineral mix (mg/100g pakan/diet): } \mathrm{KH}_{2} \mathrm{PO}_{4} 412 ; \mathrm{CaCO}_{3} 282 ; \mathrm{Ca}\left(\mathrm{H}_{2} \mathrm{PO}_{4}\right) 618 ; \mathrm{FeCl}_{3} .4 \mathrm{H}_{2} \mathrm{O} 166 \text {; } \\
\mathrm{ZnSO}_{4} \text { 9.99; } \mathrm{MnSO}_{4} 6.3 ; \mathrm{CuSO}_{4} 2 ; \mathrm{CoSO}_{4} \cdot 7 \mathrm{H}_{2} \mathrm{O} 0.05 ; \mathrm{KJ} 0.15 ; \text { Dekstrin 450; Selulosa } 553.51\end{array}$} \\
\hline
\end{tabular}


AOAC (1985). Peubah yang diamati adalah pertumbuhan panjang cangkang, pertambahan bobot, persentase pertambahan bobot, konversi pakan, dan sintasan benih abalon pada akhir pemeliharaan.

Pertumbuhan abalon yang dinyatakan dengan pertambahan bobot dan persentase pertambahan bobot, konversi pakan, dan sintasan masing-masing dihitung berdasarkan rumus:

Pertambahan Bobot $(\mathrm{g})=$ Bobot Akhir - Bobot Awal

Persentase Pertambahan Bobot $(\%)=($ Bobot Akhir - Bobot Awal) x 100/Bobot Awal

Konversi Pakan = Total Konsumsi Pakan (g)/ Pertambahan Biomassa (g)

Sintasan abalon dihitung dengan menggunakan rumus (Huynh \& Fotedar, 2004):

$$
\mathrm{SR}=\mathrm{N}_{\mathrm{t}} / \mathrm{N}_{\mathrm{o}} \times 100
$$

di mana:

SR : Sintasan biota uji (\%)

$\mathrm{N}_{\mathrm{o}}$ : Jumlah biota uji pada awal penelitian (ekor)

$\mathrm{N}_{\mathrm{t}}$ : Jumlah biota uji yang hidup pada akhir penelitian (ekor)

Untuk mengetahui pengaruh rasio bahan utama pakan terhadap pertumbuhan, konversi pakan, dan sintasan, dianalisis dengan ANOVA dan dilanjutkan dengan uji Least Significant Differences (LSD). Sebagai data penunjang dilakukan pengukuran parameter lingkungan perairan seperti suhu, salinitas, $\mathrm{pH}$, oksigen terlarut, dan amoniak. Suhu diukur menggunakan termometer digital, $\mathrm{pH}$ dengan $\mathrm{pH}$ meter, oksigen terlarut dengan DO meter, amoniak dengan spektrometer.

\section{HASIL DAN BAHASAN}

Pertumbuhan panjang cangkang rata-rata abalon selama penelitian disajikan pada Gambar 1. Hasil analisis proksimat dari pelet kering yang berasal dari bahan rumput laut dengan komposisi antara Ulva sp. dan Gracilaria sp. disajikan pada Tabel 1. Pelet tersebut digunakan sebagai pakan benih abalon selama penelitian.

Dari Gambar 1, terlihat bahwa benih abalon mampu merespons formula pakan untuk meningkatkan panjang cangkang abalon sampai akhir penelitian. Peningkatan panjang cangkang terjadi pada semua perlakuan sampai minggu ke-4. Hal ini diduga karena benih baru beradaptasi dengan formula pakan yang mengandung makroalga yang dikeringkan menjadi tepung dan ditambah sumber protein lain berupa tepung ikan yang dilengkapi vitamin dan mineral. Pada minggu ke- 5 terlihat pertumbuhan panjang cangkang pada pakan D yang mengandung proporsi makroalga Ulva sp. dan Gracilaria sp. 1:3 atau 25,75\% mengalami penurunan sampai akhir penelitian. Panjang cangkang tertinggi diperoleh pada pakan A (21,00 mm) dan terendah pada pakan buatan D yaitu 19,11 mm. Pada penelitian Priyambodo et al. (2005) melaporkan bahwa benih abalon dari jenis $H$. asinina yang dipelihara selama 6 bulan dan diberi pakan Gracilaria mencapai panjang cangkang sekitar $1,75 \mathrm{~cm}$, sementara Indarjo et al. (2007) melaporkan bahwa pemberian pakan Gracilaria sp. memberikan pertumbuhan panjang cangkang yang paling tinggi untuk abalon $H$. asinina jika dibandingkan dengan pakan buatan (pelet), dan pakan kombinasi.

Susanto et al. (2009) menyatakan abalon $H$. squamata dengan pemberian pakan Gracilaria. menghasilkan pertumbuhan panjang cangkang lebih baik dibanding pemberian pakan pelet, tetapi dengan pemberian pakan kombinasi memberikan pertumbuhan panjang cangkang terbaik. Rahmawati et al. (2008) menyebutkan bahwa rumput laut jenis Ulva sp. dan Gracilaria sp. adalah jenis rumput laut yang baik untuk pertumbuhan abalon ( $H$. squamata) dibanding jenis rumput laut lainnya, sementara menurut Capinpin \& Corre (1996) dengan menggunakan Gracilaria sp. sebagai pakan dapat memacu pertumbuhan dan dianggap cocok untuk budidaya abalon.

Pemberian pakan rumput laut segar untuk abalon $H$. squamata lebih cepat tumbuh dibanding $H$. asinina. Pemberian pakan pelet, kombinasi pelet dan Gracilaria sp. telah dilakukan dan memberikan respons pertumbuhan, tetapi pertumbuhan panjang cangkang yang lebih baik adalah dengan pemberian kombinasi pelet dan Gracilaria sp. Hal ini diduga pakan kombinasi tersebut dapat memenuhi kebutuhan nutrisi untuk pertumbuhan abalon, di mana nutrisi yang terdapat pada pelet dapat melengkapi kekurangan dari nutrisi dalam rumput laut. Sementara pemberian pakan pelet dari sumber bahan rumput laut ditambah tepung ikan sebagai sumber protein (Tabel 2 ), dapat 


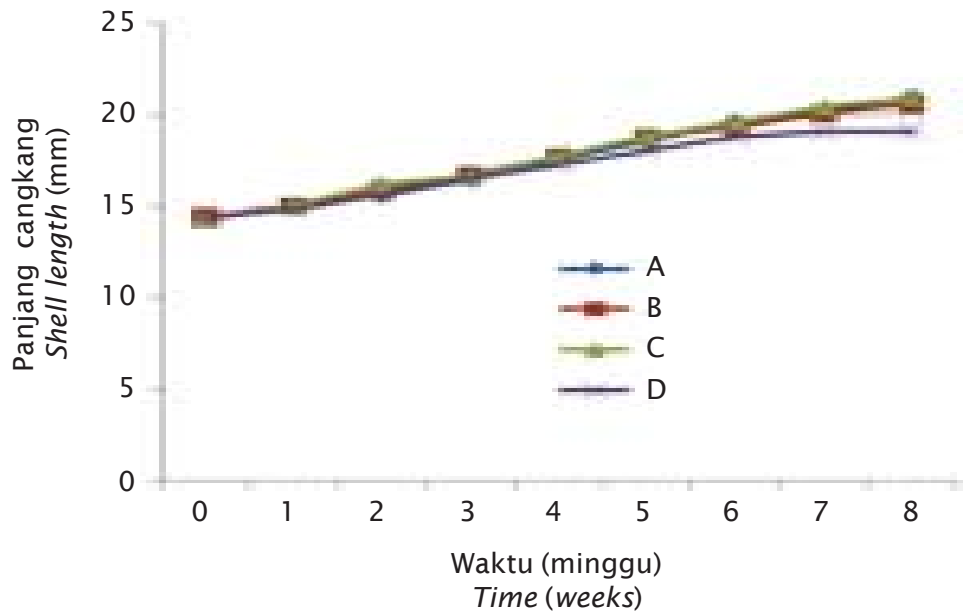

Gambar 1. Pertumbuhan panjang cangkang abalon selama penelitian. Perlakuan (A) Ulva sp. : Gracilaria sp. = 4:0; (B) Ulva sp. : Gracilaria sp. $=3: 1 ;$ (C) Ulva sp. : Gracilaria sp. $=2: 2 ;$ (D) Ulva sp. : Gracilaria sp. = 1:3

Figure 1. The growth of shell length abalone during the experiment. The treatment (A) Ulva sp. : Gracilaria sp. = 4:0; (B) Ulva sp. : Gracilaria sp. = 3:1; (C) Ulva sp. : Gracilaria $s p .=2: 2 ;(D)$ Ulva sp. : Gracilaria sp. $=1: 3$

Tabel 2. Bobot akhir, pertambahan bobot, panjang cangkang, sintasan, dan konversi pakan yuwana abalon pada akhir penelitian

Table 2. Final body weight, percentage weight gain, shell length, survival rate, and feed convertion ratio of abalone juveniles at final experiment

\begin{tabular}{cccccc}
\hline $\begin{array}{c}\text { Pakan } \\
\text { (Proporsi Ulva sp. : } \\
\text { Gracilaria sp.) } \\
\text { Diets (Ulva sp. : } \\
\text { Gracilaria sp. } \\
\text { proportion) }\end{array}$ & $\begin{array}{c}\text { Bobot } \\
\text { akhir } \\
\text { Final } \\
\text { body } \\
\text { weight } \\
\mathbf{( g )}\end{array}$ & $\begin{array}{c}\text { Pertambahan } \\
\text { bobot } \\
\text { Weight } \\
\text { gain } \\
\mathbf{( \% )}\end{array}$ & $\begin{array}{c}\text { Panjang } \\
\text { cangkang } \\
\text { Shell } \\
\text { length } \\
\text { (mm) }\end{array}$ & $\begin{array}{c}\text { Sintasan } \\
\text { Survival } \\
\text { rate } \\
\text { (\%) }\end{array}$ & $\begin{array}{c}\text { Konversi } \\
\text { pakan } \\
\text { Feed } \\
\text { conversion } \\
\text { ratio }\end{array}$ \\
\hline (A) $4: 0$ & $1.48^{\mathrm{b}}$ & $189.54^{\mathrm{b}}$ & 21.00 & 96.67 & 4.05 \\
(B) $3: 1$ & $1.37^{\mathrm{b}}$ & $179.33^{\mathrm{b}}$ & 20.60 & 95.00 & 4.11 \\
(C) $2: 2$ & $1.43^{\mathrm{b}}$ & $176.74^{\mathrm{b}}$ & 20.90 & 95.00 & 4.18 \\
(D) $1: 3$ & $1.15^{\mathrm{a}}$ & $125.49^{\mathrm{a}}$ & 19.11 & 88.33 & 4.57 \\
\hline
\end{tabular}

") Angka dalam kolom yang diikuti huruf superskrip berbeda, menunjukkan berbeda nyata

*) The values in the coloum followed by different letter are significantly different $(P<0.05)$

meningkatkan pertambahan bobot yuwana abalon sebesar 125,49\%-189,54\%. Menurut Suwirya et al. (2002), pakan diperlukan untuk pertumbuhan, kesehatan ikan, dan untuk peningkatan mutu produksi. Untuk keperluan tersebut ikan memerlukan nutrien berupa protein, lemak, karbohidrat, vitamin, dan mineral yang kebutuhannya berbeda sesuai dengan umur dan jenis abalon.

Hasil penelitian menunjukkan bahwa pemberian pakan buatan (pelet) dengan proporsi Ulva sp. dan Gracilaria sp. yang 
berbeda untuk yuwana abalon memberikan pengaruh yang nyata terhadap pertumbuhan abalon yang dapat dilihat dengan bobot akhir dan persentase pertambahan bobot akhir $(P<0,05)$ (Tabel 2).

Pada Tabel 2 terlihat bahwa abalon yang dipelihara selama penelitian menunjukkan pertambahan bobot yang terbaik adalah perlakuan A yaitu pemberian pakan dengan proporsi Ulva sp. dan Gracilaria sp. 4:0, bila dibandingkan dengan perlakuan lainnya. Dari hasil analisis statistik menunjukkan bahwa pemberian pakan berupa pakan buatan (pelet) dengan proporsi yang berbeda memberikan pengaruh nyata $(P<0,05)$ terhadap bobot akhir dan persentase pertambahan bobot abalon. Selanjutnya untuk mengetahui perbedaan di antara perlakuan, pengujian dilanjutkan dengan uji LSD (Least Significant Difference by Student's T) yaitu pada perlakuan A berbeda dengan perlakuan $D$, tetapi tidak berbeda dengan perlakuan B dan C, secara rinci dapat terlihat pada Tabel 2 .

Sampai akhir penelitian diperoleh data peningkatan pertumbuhan mutlak benih abalon untuk perlakuan $A, B, C$, dan D seperti terlihat pada Gambar 2. Pertumbuhan mutlak benih abalon yang terbaik adalah pada perlakuan A diikuti perlakuan C, B, dan D. Perlakuan A memberikan pertumbuhan mutlak terbaik diduga karena pelet tersebut dengan proporsi bahannya berasal dari 100\% Ulva sp. yang memiliki kandungan protein sebesar $18,70 \%$ dan kadar lemak sebesar $2,51 \%$, serta kadar abu sebesar 11,42\%.

Sampai akhir penelitian diperoleh persentase sintasan benih abalon dengan pemberian pakan dengan proporsi Ulva sp. dan Gracilaria sp. berbeda menghasilkan sintasan antara 88,33\% sampai 96,67\% (Gambar 3). Persentase sintasan tertinggi dicapai pada perlakuan A dan yang terendah pada perlakuan D. Hal ini menunjukkan bahwa kandungan nutrisi pada pakan yang memiliki proporsi Ulva sp. antara 50\%-100\% dalam pelet memberikan respons yang baik dalam menopang sintasan benih abalon $\mathrm{H}$. squamata.

Konversi pakan abalon dipengaruhi oleh proporsi Gracilaria sp./Ulva sp. dalam pakannya (Tabel 2). Konversi pakan yang tertinggi diperoleh pada abalon yang diberi pakan D dengan proporsi Ulva sp. dan Gracilaria sp. ( $1: 3$ atau $25 \%: 75 \%$ ) yaitu sebesar 4,57 dan yang terendah adalah pakan A dengan proporsi Ulva sp. dan Gracilaria sp. (4:0 atau 100\%:0\%) yaitu 4,05 . Dengan semakin kecil nilai konversi pakan dapat menunjukkan bahwa pakan dimanfaatkan secara lebih efisien oleh benih abalon untuk pertumbuhannya atau kualitas pakannya yang lebih baik. Hal ini dapat diindikasikan bahwa jenis pakan buatan (pelet) dengan proporsi Ulva sp. dan Gracilaria sp. (4:0 atau 100\%:0\%) sesuai untuk meningkatkan pertumbuhan benih abalon.

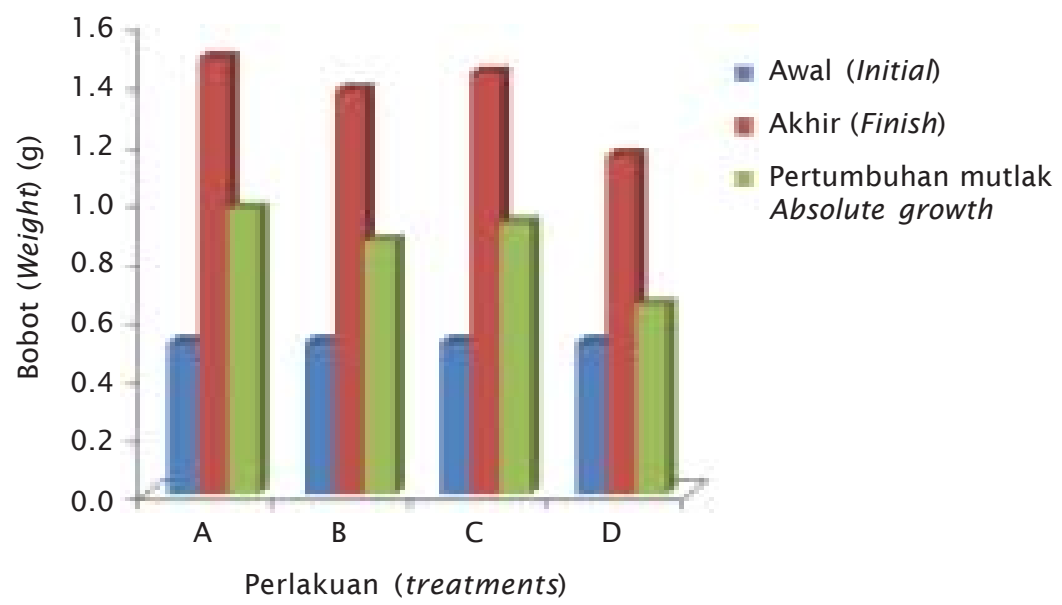

Gambar 2. Pertambahan bobot mutlak (g) yuwana abalon H. squamata selama penelitian

Figure 2. Absolute weight gain ( $g$ ) of juveniles abalone, $\boldsymbol{H}$. squamata during experiment 


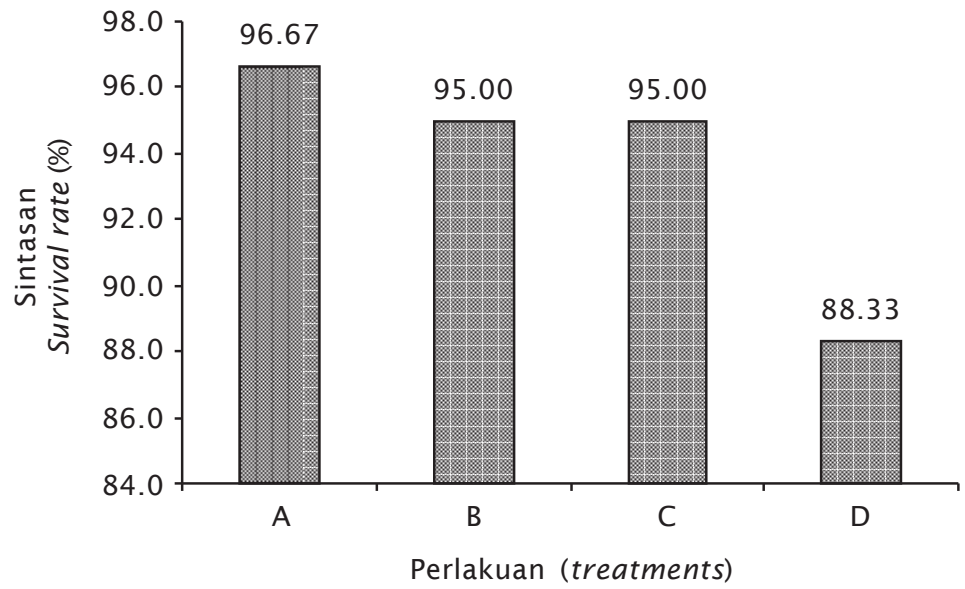

Gambar 3. Sintasan benih abalon, H. squamata dengan pemberian pakan buatan berbeda selama penelitian

Figure 3. Survival rate of abalone juvenile, $\boldsymbol{H}$. squamata fed with experimental diet during experiment

Pakan buatan (pelet) dengan kandungan makroalga berupa Ulva sp. mempunyai tekstur yang lebih lunak dibandingkan dengan Gracilaria sp. sehingga lebih mudah dicerna dan diperoleh lebih banyak energi tercerna. Abalon menghabiskan sekitar 25\%-30\% dari energi tercernanya untuk respirasi tergantung spesiesnya (Donovan \& Carefoot, 1998; Gomes-Montes, 2003), dan sisanya 70\%-75\% untuk kebutuhan lain termasuk untuk pertumbuhan.

Benih abalon selama pemeliharaan dapat merespons pakan pelet yang diberikan dan terlihat adanya peningkatan ukuran panjang cangkang dengan warna yang lebih cerah. Hal ini dapat terlihat benih abalon yang diberi pakan (A) pertumbuhan cangkangnya terlihat lebih cerah bila dibandingkan dengan pemberian pakan (D) (Gambar 4).

Pengukuran kualitas air selama penelitian menunjukkan nilai yang masih layak untuk pemeliharaan yuwana abalon, di mana suhu berkisar antara $28,6^{\circ} \mathrm{C}-29,0^{\circ} \mathrm{C}$; salinitas $34-35$ ppt; oksigen terlarut 5,7-5,8 mg/L; pH 8,028,21 ; dan amonia 0,005-0,010 mg/L. Menurut Irwan (2006), suhu yang optimal untuk abalon berkisar antara $24^{\circ} \mathrm{C}-30^{\circ} \mathrm{C}$, sedangkan salinitas optimum antara 30-35 ppt. Menurut Fallu (1991), kisaran salinitas normal yang cocok untuk pertumbuhan abalon yaitu berkisar 33\%-35\% dan pertumbuhan hewan laut tidak optimal pada salinitas di atas 35\%. Susanto et al. (2009) melaporkan bahwa untuk pemeliharaan abalon menghendaki suhu air berkisar

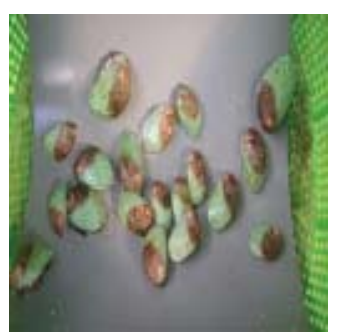

(A) Ulva sp.: : Gracilaria sp. $=4: 0$

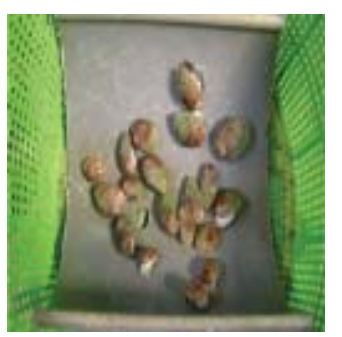

(B) Ulva sp.: : Gracilaria sp. $=3: 1$

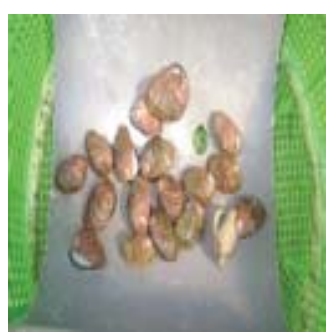

(C) Ulva sp. : Gracilaria sp. $=2: 2$

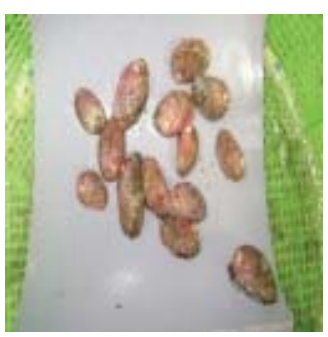

(D) Ulva sp. : Cracilaria sp. $=1: 3$

Gambar 4. Warna cangkang benih abalon H. squamata yang diberi pakan buatan (pelet) selama penelitian

Figure 4. The shell colour of abalone juvenile, $\boldsymbol{H}$. squamata fed test diet during experiment 
$27,2^{\circ} \mathrm{C}-29,9^{\circ} \mathrm{C}$; salinitas $33-35 \mathrm{ppt}$; oksigen terlarut 4,8-5,44 mg/L; $\mathrm{pH} 8,02-8,21$; dan amonia 0,017-0,048 mg/L. Rusdi et al. (2009) kualitas air untuk pemeliharaan abalon dengan suhu $27,8^{\circ} \mathrm{C}-29,8^{\circ} \mathrm{C}$; salinitas $33-34 \mathrm{ppt}$;

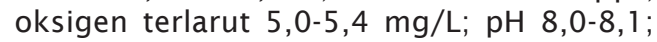
amonia 0,015-0,052 mg/L.

\section{KESIMPULAN DAN SARAN}

Pakan buatan dengan proporsi Ulva sp. dan Gracilaria sp. yang berbeda dalam pakan pelet berpengaruh terhadap pertumbuhan abalon dan menurunkan konversi pakan. Pakan buatan (pelet) dengan proporsi Ulva sp. dan Gracilaria sp. 4:0 (100\%:0\%) memberikan persentase pertambahan bobot tertinggi $(189,54 \%)$; dan sintasan benih abalon sebesar $96,67 \%$.

Perlu dilakukan penelitian lebih lanjut untuk mengetahui kadar protein optimal pakan buatan dalam mendukung pertumbuhan benih abalon Haliotis squamata.

\section{DAFTAR ACUAN}

AOAC (Assosiation of Official Analytical Chemist). 1985. Official methods of analysis. $14^{\text {th }}$ edition. Washington D.C., 1,141 pp.

Capinpin, Jr.E.C. \& Corre, K.G. 1996. Growth rate of the Philippine abalone, Haliotis asisina fed an artificial diet and macroalgae. Aquaculture, 144(1-3): 81-89.

Chen, J.C. \& Chen, W.C. 2000. Salinity tolerance of Haliotis diversicolor supertexta at different salinity and temperature levels. Aquaculture, 181: 191-203.

Donovan, D. \& Carefoot, T. 1998. Effect of activity on energy allocation in the northern abalone Haliotis kamtschatkana (jones). J. Shellfish Research, 17: 729-736.

Huynh, M.S. \& Fotedar, R. 2004. Growth, survival, hemolymph osmolality and organosomatic indices of the western king prawn (Penaeus laticulatus Kihinouye, 1896) reared at different salinities. Aquaculture, 234: 601-614.

Fallu, R. 1991. Abalone Farming. Fishing News Book. London, $196 \mathrm{pp}$.

Fleming, A.E. \& Hone, P.W. 1996. Abalon Aquaculture, Elsevier Science, Aquaculture.

Gomes-Montes, L., Garcia-Esquivel, Z., D’Abramo, L.R., Shimada, A., VasquesPelaez, C., \& Viana, M.T. 2003. Effect of dietary protein:energy ratio on intake, growth and metabolism of juvenile green abalone, Haliotis fulgens. Aquaculture, 220: 769-780.
Gordon, H.R. \& Cook, P.A. 2004. World abalone fisheries and aquaculture update: supply and market dynamics. J. Shellfish Res., 23: 935-939.

Indarjo, A., Hartati, R., Samidjan, I., \& Anwar, S. 2007. Pengaruh pakan Gracilaria sp. dan pakan buatan terhadap pertumbuhan abalon Haliotis asinina. Prosiding Seminar Nasional Moluska dalam Penelitian, Konservasi, dan Ekonomi, hlm. 215-228.

Irwan, J.E. 2006. Pengembangan budidaya abaIon (Haliotis asinina L.) produksi hatcheri di Indonesia. Jurusan Perikanan, UNHALU, Kendari, Sulawesi Tenggara, $21 \mathrm{hlm}$.

Priyambodo, B., Sofyan, Y., \& Suastika Jaya, I.B.M. 2005. Produksi benih kerang abalon (Haliotis asinina) di Loka Budidaya Laut Lombok. Prosiding Seminar Nasional Tahunan Hasil Penelitian Perikanan dan Kelautan. Perikanan dan Kelautan UGM. Yogyakarta, hlm. 144-148.

Octaviany, M.J. 2007. Beberapa catatan penting tentang aspek biologi dan perikanan abalon. Jakarta, Oseana, XXXII(4): 39-47.

Rahmawati, R., Rusdi, I., \& Susanto, B. 2008. Studi tentang pertumbuhan abalon Haliotis squamata (Reeve, 1846) dengan pemberian pakan makroalga yang berbeda. Teknologi Budidaya Perikanan Sosial Ekonomi Kelautan dan Perikanan. Prosiding Seminar Nasional Perikanan 2008. STP Jakarta, hlm. 342-349.

Rahmawati, R., Rusdi, I., Susanto, B., \& Ismi, S. 2009. Produksi massal benih abalon Haliotis squamata (Reeve, 1846). Pusat Riset Perikanan Budidaya. Forum Inovasi Teknologi Akuakultur, Surabaya, hlm. 85-95.

Rusdi, I., Susanto, B., \& Rahmawati, R. 2009. Pemeliharaan abalon Haliotis squamata dengan sistem pergantian air yang berbeda. Prosiding Seminar Nasional Moluska 2, "Moluska Peluang Bisnis dan Konservasi". FPIK-IPB. Bogor, V: 72-81.

Singhagraiwan, T., Doi, M., \& Sasaki, M. 1992. Salinity tolerance of juvenile donkey's ear abalone, Haliotis asinina Linne. Thai Mar. Fish. Res. Bull., 3: 71-77.

Susanto, B., Hanafi, A., Zafran, \& Ismi, S. 2007. Pematangan gonad induk dan perbaikan kualitas benih abalon (Haliotis squamata). Laporan Teknis BBRPBL, Gondol-Bali, 17 hlm. (Inpress).

Susanto, B., Rusdi, I., Ismi, S., \& Rahmawati, R. 2009. Pemeliharaan yuwana abalon (Haliotis squamata) turunan F-1 secara 
terkontrol dengan jenis pakan berbeda. Suwirya, K., Giri, N.A., \& Marzuqi, M. 2002. Pusat Riset Perikanan Budidaya. J. Ris. Informasi nutrisi ikan untuk menunjang Akuakultur, 5(2): 199-209. pengembangan budidaya Laut. Prosiding Seminar Nasional. Universitas Mataram, Mataram, hlm. 233-238. 